\title{
PERAN KONTROL DIRI DALAM MOTIVASI BERPRESTASI DAN PERFEKSIONISME TERHADAP PROKRASTINASI AKADEMIK MAHASISWA
}

\author{
${ }^{1}$ Yusuf Syaifulloh*, ${ }^{2}$ Santi Susanti, ${ }^{3}$ Mardi \\ ${ }^{123}$ Program Studi Pendidikan Ekonomi, Universitas Negeri Jakarta \\ e-mail: yusufsyaifulloh232323@ gmail.com*
}

\begin{abstract}
This reseach aims to examined the role of Self-Control as a mediating variable in the effect of Academic Perfection on Academic Procrastination. Quantitative method was used with data collection techniques by online questionnaire's. Population in this research were students of Economics Education Faculty of Economics UNJ on 2013-2016 all concentration which they currently doing their S1 thesis. 145 people to be the sample were counted with proportional random sampling techniques. Techniques of data analysis used test for requirement analysis, test for hyphothesis and path analysis. The result of test for requirements analysis showed that data was normal and linearly distributed. Test for hypothesis result concluded all of them were accepted and path analysis result showed Self-Control was able to mediate dependents and independents variables. The ability of Achievement Motivation, Perfectionism and Self-Control to define Academic Procrastination are 31,4\%, while the rest were influenced by other variables that are not used. From this research concluded that were need for developing interpersonal skill to avoid procrastination behavior specially on academic realm.
\end{abstract}

Keywords: achievment motivation; perfectionism; academic procrastination; self-control

\begin{abstract}
ABSTRAK
Penelitian ini dilakukan untuk mengetahui peran kontrol diri memediasi pengaruh motivasi berprestasi dan perfeksionisme terhadap prokrastinasi akademik. Jenis penelitian ini adalah metode kuantitif dengan teknik pengumpulan data yang digunakan adalah penyebaran kuesioner secara online. Populasi terjangkau dalam penelitian ini adalah mahasiswa Pendidikan Ekonomi Fakultas Ekonomi UNJ seluruh konsentrasi 2013-2016 yang sedang dalam proses menyelesaikan skripsi. 145 orang adalah sampel yang digunakan dengan teknik perhitungan sampel acak proporsional. Teknik analisis data yang digunakan adalah uji prasyarat analisis, uji hipotesis, analisis deskriptif dan analisis jalur (path). Hasil uji prasyarat analisis menunjukkan bahwa data berdistribusi normal dan linear. Uji hipotesis menujukkan keseluruhan dari hipotesis yang dirumuskan sesuai, serta hasil analisis jalur diketahui menghasilkan informasi bahwa Kontrol Diri mampu memediasi variabel bebas terhadap terikat. Kemampuan Motivasi Berprestasi, Perfeksionisme dan Kontrol diri mampu menjelaskan Prokrastinasi Akademik sebesar 31,4\% selebihnya dijelaskan oleh variabel yang tidak digunakan pada penelitian ini. Hasil penelitian ini menyimpulkan bahwa perlu adanya pengembangan intrapersonal mahasiswa agar terhindar dari perilaku prokrastinasi khususnya pada ranah akademik.
\end{abstract}

Kata kunci: motivasi berprestasi; perfeksionisme; prokrastinasi akademik; kontrol diri

Cara mengutip: Syaifulloh, Y., Susanti, S. \& Mardi. (2021). Peran Kontrol diri dalam Motivasi Berprestasi dan Perfeksionisme terhadap Prokrastinasi Akademik Mahasiswa. Inteligensi: Jurnal Ilmu Pendidikan, 4(1), 27-36 


\section{PENDAHULUAN}

Pendidikan adalah suatu konsep berkenaan dengan proses belajar setiap individu sebagai kebutuhan utama dalam rangka mengembangkan potensi diri. Berbagai tantangan dan peluang dalam dunia Pendidikan semakin kompleks, mulai dari ketersediaan sumber daya manusia sampai dengan luarannya yang harus bisa menyesuaikan diri dengan perkembangan zaman. Pada era disrupsi ini, kekuatan daya saing menjadi salah satu hal yang perlu dipertajam seperti kemampuan manajemen waktu dan aktivitas dengan efektif dan efisien (Triyono \& Khairi, 2018). Namun sampai dengan hari ini masih terdapat ketidaksiapan masyarakat dalam menghadapi tantangan tersebut. Kebiasaan seperti menunda-nunda pekerjaan bahkan untuk perihal yang wajib adalah salah satu bentuk ketidaksiapan yang masih terjadi saat ini (Novera and Thomas, 2018). Menurut Zahraningsih \& Abdurrahman (2019) perilaku penundaan sering terjadi pada siapapun tanpa memandang gender, umur, ataupun status pekerjaan, diperkirakan prokrastinasi pada maha siswa telah mencapai angka $90 \%$ dengan $25 \%$ diantaranya sudah masuk dalam kategori akut dan memasuki tahap hampir dan telah drop out dari perguruan tinggi. Studi lacak pada program studi Pendidikan Ekonomi FE UNJ mengenai perilaku prokrastinasi telah dilakukan melalui data dengan hasil yang menunjukkan bahwa terdapat cukup banyak mahasiswa yang terlambat lulus atau lulus lebih dari delapan semester dengan rincian sebagai berikut:
Tabel 1. Rekapitulasi Jumlah Mahasiswa yang Lulus Lebih Dari Delapan Semester

\begin{tabular}{ccccc}
\hline No & Angkatan & Total & Jumlah & Persentase \\
\hline $\mathbf{1}$ & 2012 & 257 & 110 & $42,80 \%$ \\
$\mathbf{2}$ & 2013 & 264 & 77 & $29,17 \%$ \\
$\mathbf{3}$ & 2014 & 232 & 70 & $30,17 \%$ \\
$\mathbf{4}$ & 2015 & 270 & 64 & $23,70 \%$ \\
& Rata-rata & & 80,25 & $31,46 \%$ \\
\hline
\end{tabular}

Data tersebut menunjukkan bahwa terdapat perilaku penundaan atas beberapa tugas akademik yang menyebabkan keterlambatan penyelesaian studi. Perilaku menunda tersebut cukup meresahkan mahasiswa secara pribadi karena harus berusaha mengejar sesuatu yang telah terlewati atau terburu-buru dalam pengerjaan tugas sebab sebelumnya tidak banyak memahami materi. Steel (2007) mengungkapkan bahwa terdapat beberapa faktor yang menyebabkan terjadinya perilaku penundaan akademik adalah rendahnya motivasi untuk berprestasi, perfeksionisme dan kurang baiknya kontrol diri seseorang. Prokrastinasi akademik merupakan perilaku yang perlu dihindari sebab dapat menyebabkan gangguan kesehatan seperti strees, cemas, mood swing, dan gangguan kesehatan lainnya sehingga setiap potensi tidak termaksimalkan secara penuh.

$$
\text { Indeks Pembangunan Manusia }
$$
(IPM) di Indonesia pada data yang diperoleh dari Badan Pusat Statistik (BPS) tahun 2020 menunjukkan angka sebesar $71,92 \%$. Angkat tersebut tergolong sedang untuk status pembangunan manusia di Indonesia. Sehingga yang paling mengkhawatirkan adalah pembangunan manusia ini akan semakin menurun dikarenakan semakin banyaknya perilaku prokrastinasi akademik mengingat situasi hari ini sangat mendorong seseorang 
mudah melakukannya melalui pembenaran karena situasi yang memang sedang tidak normal karena Pandemi Covid-19. Penelitian yang dilakukan oleh Novera \& Thomas (2018) pada mahasiswa semester akhir menujukkan bahwa terdapat 31,4\% tergolong tingkat prokrastinasi tinggi dan $28 \%$ dalam tingkat sedang. Sehingga tedrdapat $59,4 \%$ dan lebih dari setengahnya melakukan tindakan menunda. Menurut Hartantya \& Hakim (2016) variable yang dapat memediasi korelasi impulisiveness dan prokrastinasi akademik adalah control diri yang menujukan bahwa variable teresebut kompleks.

\section{METODE PENELITIAN}

Jenis penelitian yang digunakan adalah metode kuantitatif dengan data primer yang dikumpulkan melalui kuesioner online. Sugiyono (2017) menjelaskan, metode survei dalam metode penelitian kuantitatif digunakan untuk memperoleh data yang terjadi pada masalalu maupun masa kini, tentang berbagai hal sebagai basis data untuk menguji variable yang diabil dari sample tertentu. Metode ini digunakan karena sesuai dengan tujuan dalam penelitian untuk mendapatkan bukti/konfirmasi atas informasi yang diperoleh dan diharapkan dari penelitian. Populasi terjangkau sebanyak 231 orang yang terdiri dari mahasiswa Pendidikan Ekonomi FE UNJ Angkatan 2013-2016 seluruh konsentrasi yang sedang masih mengerjakan skripsi per 30 Juni 2020. Teknik pengambilan sampel menggunakan proportional random sampling dengan perhitungan berdasarkan panduan Isaac \& Michael dengan taraf kesalahan 5\% yakni didapat 145 orang. Berikut ini adalah sebaran data hitung populasi serta sampel penelitian yang disajikan tabel 2 berikut.

\section{Tabel 2. Data Populasi dan Sampel Penelitian}

\begin{tabular}{lcc}
\hline Konsentrasi/Angkatan & Populasi & Sampel \\
Pend. Akuntansi/2016 & 49 orang & 31 orang \\
Pend. AP/2016 & 71 orang & 44 orang \\
Pend. Ekop/2016 & 68 orang & 42 orang \\
Pend. Akuntansi/2015 & 9 orang & 6 orang \\
Pend. AP/2015 & 2 orang & 1 orang \\
Pend. Ekop/2015 & 14 orang & 10 orang \\
Pend. Akuntansi/2014 & 7 orang & 4 orang \\
Pend. AP/2014 & 2 orang & 1 orang \\
Pend. Ekop/2014 & - & - \\
Pend. Akuntansi/2013 & 1 orang & 1 orang \\
Pend. AP/2013 & 1 orang & 1 orang \\
Pend. Ekop/2013 & 7 orang & 4 orang \\
\multicolumn{1}{c}{ Jumlah } & 231 orang & 145 orang \\
\hline
\end{tabular}

Teknis analisis data yang digunakan dalam penelitian ini adalah uji prasyarat analisis (uji normalitas dan linearitas), uji hipotesis (uji t, dan koefisien determinasi), analisis deskriptif dan analisis jalur (path).

\section{HASIL DAN PEMBAHASAN}

Hasil statistik deskriptif berupa penggambaran variabel-variabel yang digunakan dalam penelitian. Berdasarkan data yang diperoleh dari 145 orang sampel, rata-rata nilai prokrastinasi akademik 71,77; motivasi berprestasi 74,81; perfeksionisme 64,66; dan kontrol diri 79,32 disimpulkan bahwa setiap variabel memiliki dominasi diatas rata-rata. Pengujian hipotesis dapat dilakukan menggunakan uji statistik $\mathrm{t}$ secara parsial dan analisis jalur untuk menguju hipotesis mediasi. Berikut ini adalah hasil uji $t$ secara parsial: 
Tabel 3. Hasil Uji t Motivasi

Berprestasi, Perfeksionisme dan

Kontrol Diri terhadap Prokrastinasi

Akademik

\begin{tabular}{lcc}
\hline \multicolumn{1}{c}{ Variabel } & Uji t & Sig. \\
Motivasi Berprestasi & -2.568 & .011 \\
Perfeksionisme & 2.896 & .004 \\
Kontrol Diri & -5.197 & .000 \\
\hline
\end{tabular}

Nilai tabel pada tabel statistik dengan taraf kesalahan 5\% dan df dari 145 adalah 141 menunjukkan angka sebesar 1,97693. Hasil olah data di atas menujukkan bahwa seluruh variabel memiliki $t_{\text {hitung }}$ lebih besar daripada $t_{\text {tabel. }}$. Dengan keterangan tersebut dapat diinterpretasikan sebagai berikut; ada pengaruh negatif motivasi terhadap prokrastinasi akademik, pengaruh positif perfeksionisme terhadap prokrastinasi akademik, pengaruh negatif kontrol diri terhadap prokrastinasi akademik. Serta hasil uji t ini menujukkan bahwa seluruh variabel berpengaruh dengan signifikan ditunjukkan dengan nilai Sig. yang didapatkan seluruhnya dibawah 0,05. Pada pengujian analisis jalur, digunakan dua model pola yang berfungsi untuk mengetahui bagaimana pengaruhnya yang disajikan pada tabel 4 dan 5 berikut.

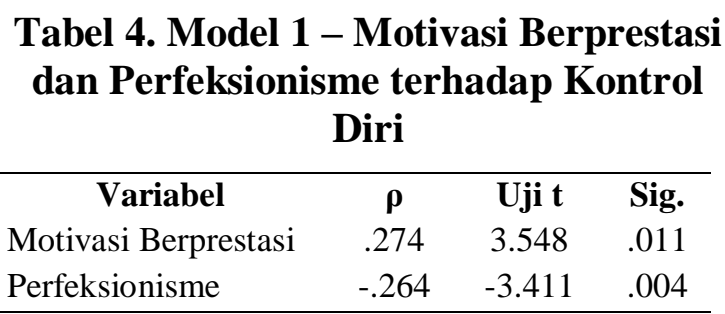

Tabel 5. Model 2 - Motivasi Berprestasi, Perfeksionisme dan Kontrol Diri terhadap Prokrastinasi Akademik

\begin{tabular}{lccc}
\hline \multicolumn{1}{c}{ Variabel } & $\boldsymbol{\rho}$ & Uji t & Sig. \\
Motivasi Berprestasi & -.186 & -2.568 & .011 \\
Perfeksionisme & .209 & 2.896 & .004 \\
Kontrol Diri & -.391 & -5.197 & .000 \\
\hline
\end{tabular}

Hasil pengujian di atas kemudian menjadi dasar perhitungan koefisien jalur yang dihasilkan masing-masing fungsi. Perhitungannya dapat dilakukan dengan penjelasan sebagai berikut:

1) Peran Kontrol Diri (Z) memediasi pengaruh Motivasi Berprestasi $\left(\mathrm{X}_{1}\right)$ terhadap Prokrastinasi Akademik (Y) Perhitungan koefisien jalur I:

$$
\begin{aligned}
& =\rho_{\mathrm{Yx}_{1}}+\left(\rho_{\mathrm{Zx}_{1}} \times \rho_{\mathrm{YZ}}\right) \\
& =-0,186+(0,274 \times-0,391) \\
& =-0,186+-0,107 \\
& =-0,293(-29,3 \%)
\end{aligned}
$$

Pada perhitungan di atas dapat dideskripsikan bahwa koefisien jalur pada pengaruh tidak langsung antara motivasi berprestasi terhadap prokrastinasi akademik adalah -0,293. Maka kontrol diri mampu memediasikan model regresi ini.

2) Peran Kontrol Diri ( $Z$ ) memediasi pengaruh Perfeksionisme $\left(\mathrm{X}_{2}\right)$ terhadap Prokrastinasi Akademik (Y) Perhitungan koefisien jalur II:

$$
\begin{aligned}
& =\rho_{\mathrm{YX}_{2}}+\left(\rho_{\mathrm{ZX}_{2}} \times \rho_{\mathrm{YZ}}\right) \\
& =0,209+(0,264 \times-0,391) \\
& =0,209+0,103 \\
& =0,311(31,1 \%)
\end{aligned}
$$

Pada perhitungan di atas dapat mendeskripsikan bahwa koefisien jalur pada pengaruh tidak langsung anatara perfeksionisme terhadap prokrastinasi akademik adalah 0,311 .

Hasil uji koefisien determinasi menujukkan angka 0,314 yang membuktikan bahwa kekuatan variabel motivasi berprestasi, perfeksionisme dan kontrol diri mampu menjelaskan prokrastinasi akademik dengan persentase $31,4 \%$, selebihnya dipangurhi atau dapat dijelaskan melalui faktor lain. 


\section{Motivasi Berprestasi terhadap Prokrastinasi Akademik}

Hasil penelitian ini mengungkapkan bahwa koefisien regresi $\mathrm{X}_{1}$ terhadap $\mathrm{Y}$ adalah -0,206 dan thitung menujukkan angka -2,568 dengan taraf signifikansi 0,011 yang menujukkan adanya pengaruh negatif motivasi berprestasi terhadap prokrastinasi akademik. Berarti bahwa jika motivasi untuk mencapai prestasi mengalami peningkatan satu titik, prokrastinasi akademik akan mengalami penurunan sebesar 0,206 pada konstanta 109,171 dengan asumsi bahwa $\mathrm{X}_{2}$ dan $\mathrm{Z}$ tidak berubah. Dapat penulis simpulkan bahwa semakin tinggi tingkat motivasi berprestasi, semakin rendah tingkat prokrastinasi akademik, dan sebaliknya.

Hasil penelitian ini didukung oleh penelitian sebelumnya oleh Sari dkk (2017) yang mengungkapkan pada penelitiannya pada mahasiswa Psikologi Universitas Tama Jagakarsa dengan hasil $t_{\text {hitung }}$ sebesar $-0,641$ yang menunjukkan danya pengaruh negatif dan disimpulkan bahwa semakin tinggi motivasi berprestasi menyebabkan semakin rendahnya prokrastinasi akademik. Selaras dengan penelitian sebelumnya yang dilakukan oleh Sprock \& Villalba (2020) yang menyatakan an inverse realtion between academic procrastination tendention and motivational attribution of achievment in students.

\section{Perfeksionisme terhadap Prokrastinasi Akademik}

Penelitian ini menghasilkan output dengan koefisien regresi $\mathrm{X}_{2}$ di dapatkan 0,206 pada konstanta 109,171 dan thitung dari uji hipotesis menujukkan hasil 2,896 dengan taraf signifikansi 0,004. Dapat menggambarkan bahwa adanya pengaruh positif antara perfeksionisme terhadap prokrastinasi akademik dan apabila terjadi peningkatan satu titik pada perfeksionisme maka akan meningkatkan sebanyak 0,206 poin pada prokrastinasi akademik dengan asumsi $\mathrm{X}_{1}$ dan $\mathrm{Z}$ tidak berubah. Selain itu, dapat disimpulkan bahwa semakin tinggi tingkat perfeksionisme mahasiswa maka akan semakin tinggi pula tingkat prokrastinasi akademiknya.

Hasil penelitian ini selaras dengan penelitian yang dilakukan sebelumnya oleh Setiawan \& Faradina (2018) pada mahasiswa Universitas Syiah Kuala yang tengah mengerjakan skripsi, mahasiswa yang memiliki tingkat perfeksionisme tinggi akan semakin tinggi pula intensitasnya dalam melakukan prokrastinasi akademik. Penelitian lain yang dilakukan oleh Ananda \& Mastuti (2013) pada siswa kelas akselerasi didapatkan hasil uji t sebesar 4,815 yang menandakan adanya penaruh positif anatara kedua variabel yakni perfeksionisme dan prokrastinasi akademik. Dalam penelitian ini menggunakan indikator yang berbeda yakni planfullness, perceived parental perfectionism dan rumination. Penelitian terdahulu oleh Margareta \& Wahyudin (2019) juga mengungkapkan hal serupa yakni semakin tinggi perfeksinisme maka demakin tinggi pula prokrastinasi akademik.

\section{Motivasi Berprestasi terhadap Kontrol Diri}

Berdasarkan hasil penelitian di atas, terdapat nilai koefisien regresi model satu yakni 0,286 pada konstanta 74,076 yang berarti setiap terdapat peningkatan satu poin pada motivasi berprestasi maka akan memengaruhi kontrol diri yang naik 
sebanyak 0,286 poin. Selain itu hasil $t_{\text {hitung }}$ menunjukkan nilai 3,548 dengan signifikansi 0,001 yang menggambarkan bahwa terdapat pengaruh positif antara motivasi berprestasi terhadap kontrol diri. Sehingga, semakin tinggi tingkat motivasi berprestasi mahasiswa akan menyebabkan semakin tinggi pula tingkat kontrol dirinya (Oktavian and Aldya, 2020).

Hasil penelitian sebelumnya yang relevan oleh Novera \& Thomas (2018) pada mahasiswa FE UNNES yang tengah mengambil mata kuliah skripsi mengungkapkan hal yang sejalan, yakni terdapat hasil $t_{\text {hitung }}$ sebesar 4,690 dengan signifikansi 0,000 yang diartikan bahwa mahasiswa yang motivasi berprestasinya tinggi akan cenderung juga kontrol dirinya tinggi ditunjukkan dengan tingkat tanggung jawab moral dan pengendalian diri yang baik. Sejalan dengan teori yang dekemukakan oleh McClelland dalam penelitian Novera \& Thomas (2018) bahwa individu yang memiliki belajar dengan cepat atau lebih baik memiliki tingkat motivasi yang tinggi untuk segera mencapai target pribadinya. Hal tersebut berkaitan dengan bagaimana motivasi berprestasi menjadi salah atu komponen yang dapat menigkatkan kontrol diri.

\section{Perfeksionisme terhadap Kontrol Diri}

Berdasarkan hasil paparan di atas bekaitan tentang hitung analisis, didapatkan pengaruh negatif yang signifikan antara perfeksionisme terhadap kontrol diri, dibuktikan dengan thitung yang didapatkan sebesar 3,411 dengan signifikansi 0,001 serta hasil koefisien regresi $\mathrm{X}_{2}$ yang menujukkan nilai $-0,229$ pada konstanta 74,076 dengan asumsi $\mathrm{X}_{1}$ tetap. Hal ini menujukkan bahwa setiap peningkatan satu poin pada perfeksionisme maka berdampak penurunan kontrol diri sebesar 0,229. Sehingga disimpulkan bahwa apabila semakin tinggi tingkat kencenderungan akan perfeksionisme mahasiswa, akan semakin rendah kontrol diri yang dimilikinya.

Penelitian ini tidak sejalan dengan penelitian sebelumnya yang dilakukan sebelumnya oleh Novera \& Thomas (2018) yakni mengemukakan semakin tinggi tingkat perfeksionisme mahasiswa FE UNNES yang tengah mengerjakan skripsi, semakin tinggi kontrol diri mahasiswa tersebut untuk mepersiapkan, memulai dan menyelesaikan skripsi yang dibuktikan dengan hasil $t_{\text {hitung }}$ sebesar 3,565 pada taraf 0,000 . Hal ini terjadi dikarenakan adanya perbedaan penulis dengan peneliti sebelumnya dalam menentukan indikator pengukuran. Teori lainnya yang dikemukakan oleh Alwisol (2018) dalam Novera \& Thomas (2018) membuktikan sesorang dengan kecenderungan carus complex memasang target yang tinggi dan kemudian mengembangkan ambisi tersebut secara berlebihan, namun akan berusaha menguatkan pertahanan diri dengan kontrol perilaku yang baik. Namun hal tersebut justru bermakna bahwa seseorang yang terlalu tinggi perfeksionismenya akan lama-kelamaan sulit mengontrol diri hingga berpengaruh negatif pada dirinya.

\section{Kontrol Diri terhadap Prokrastinasi Akademik}

Hasil di atas menujukkan koefisien regresi pada angka $-0,445$ pada konstanta 109,171 dengan asumsi bahwa $\mathrm{X}_{1}$ dan $\mathrm{X}_{2}$ tidak berubah. Hasil uji hipotesis atau $t_{\text {hitung }}$ menujukkan angka sebesar $-5,197$ dengan signifikansi 0,000 , maka dapat disimpulkan terdapat pengaruh langsung 
yang negatif antara kontrol diri terhadap variabel prokrastinasi akademik. Nilai koefisien regresi mendeskripsikan bahwa setiap adanya peningkatan satu poin pada kontrol diri maka akan menurunkan prokrastinasi akademik sebesar 0,445 poin pada prokrastinasi akademik. Dalam arti, apabila semakin tingginya tingkat kontrol diri mahasiswa maka akan semakin rendah tingkat prokrastinasi akademik dan sebaliknya. Sejalan dengan penelitian ini, penelitian sebelumnya oleh Purwanti dkk (2016) yani mengemukakan bahwa meningginya kontrol diri maka menurunkan prokrastinasi yang dilakukan oleh seseorang dalam ranah akademik dan sebaliknya. Lebih lanjut, peserta didik yang memiliki target atau terbiasa mengatur aktivitas dan tindakan pasti cenderung untuk menghindari sikap menunda-nunda pekerjaan apapun. Sejalan pula dengan hal tersebut, penelitian oleh Artanti (2019) menjelaskan tentang variabel kontrol diri yang memiliki pengaruh berlawanan dengan arah peningkatan prokrastinasi akademik yakni semakin tinggi kontrol diri maka semakin rendah tingkat prokrastinasi akademik.

\section{Motivasi Berprestasi terhadap Prokrastinasi Akademik dimediasi Kontrol Diri}

Hitung analisis yang telah dituliskan di atas, koefisien jalur menujukkan bahwa ada pengaruh langsung motivasi berprestasi terhadap prokrastinasi akademik sebesar -0,186. Sedangakan pengaruh yang tidak langsung didapatkan adalah 0,274 x 0,391 maka dihasilkan 0,107 . Selanjutnya motivasi berprestasi apabila dimediasi oleh kontrol diri dalam pengaruhnya pada prokrastinasi akademik maka didapat $-0,293$. Dalam hal ini ditemukan pengaruh negatif dari motivasi berprestasi yang dimediasi kontrol diri untuk memengaruhi prokrastinasi akademik dengan keterangan semakin tinggi motivasi berprestasi mahasiswa akan menyebabkan tingginya kontrol diri dan semakin memperkuat mahasiswa untuk menurunkan prokrastinasi akademik dan sebaliknya (Kadi, 2016).

Hasil penelitian ini sejalan dengan penelitian sebelumnya dimana mengungkapkan bahwa nilai pengaruh tidak langsung yang didapatkan adalah $11,4 \%$ lebih kecil dari pada pengaruh langsungnya yakni 15,9\%, bahwa pengaruh motivasi berprestasi dapat dimediasi oleh kontrol diri dalam pengaruhnya terhadap prokastinasi akademik (Novera and Thomas, 2018). Sejalan pula dengan hal tersebut, Tangney dkk (2004) mengemukakan saran bahwa individu yang memiliki kekuatan dalam mengontrol diri akan memiliki intervensi besar dalam memberikan perubahan positif pada kehidupannya. Secara general, hal ini manjadi alasan pada ketidakmampuan individu untuk melakukan sesuatu tanpa memikirkan dampak jangka panjang apabila kontrol diri yang dimiliki rendah. Sehingga jika motivasi berprestasi tinggi maka kontrol dirinya akan semakin tinggi dan menyebabkan semakin rendahnya tingkat prokrastinasi khususnya yang berkaitan dengan ranah akademik (Putri, 2019).

\section{Perfeksionisme terhadap Prokrastinasi Akademik dimediasi Kontrol Diri}

Koefisien jalur didapatkan pada penelitian ini yang sebelumnya dipaparkan pada pembahasan yakni jalur perfeksionisme terhadap prokrastinasi akademik secara langsung yakni 0,209, 
pengaruh tidak langsungnya sebesar $-0,264$ $\mathrm{x} 0,391=0,103$. Melalui hitung analisis tersebut diketahui jumlaj pengaruh tidak langsung yang didapatkan adalah sebesar 0,311. Sehingga dapat disimpulkan bahwa adanya pengaruh positif antara perfeksionisme terhadap prokrastinasi akademik dimediasi kontrol diri yang berarti apabila semakin tinggi perfeksionisme mahasisa maka semakin rendah kecenderungan prokrastinasi akademik terlebih apabila dimediasi oleh variabel kontrol diri. Hal ini sejalan dengan Novera \& Thomas (2018) bahwa perfeksionisme dapat berpengaruh terhadap prokrastinasi akademik. Tangney dkk (2014) perfeksionisme secara tidak langsung akan memberikan pengaruh positif apabila dimediasi kontrol diri. Yakni perfeksionisme dapat menurunkan tingkat prokrastinasi akademik apabil seseorang tersebut memiliki kontrol diri yang tinggi.

\section{SIMPULAN}

Motivasi berprestasi berpengaruh negatif terhadap prokrastinasi akademik namun positif terhadap kontrol diri, sedangkan perfeksionisme berpengaruh positif terhadap prokrastinasi akademik, dan kontrol diri berpengaruh negatif terhadap prokrastinasi akademik. Secara bersamaan motivasi berprestasi berpengaruh secara tidak langsung melalui mediasi kontrol diri terhadap prokrastinasi akademik, dan perfeksionisme berpengaruh tidak langsung melalui mediasi kontrol diri terhadap prokrastinasi akademik.

\section{DAFTAR PUSTAKA}

Alwisol (2018) Psikologi Kepribadian. Edisi Revi. Malang: UMM Press.

Ananda, N. Y. and Mastuti, E. (2013) 'Pengaruh Perfeksionisme Terhadap
Prokrastinasi Akademik pada Siswa Program Akselerasi', JURNAL Psikologi Pendidikan dan Perkembangan, 2(3), pp. 226-231.

Artanti, D. D. (2019) 'Pengaruh Kontrol Diri Terhadap Prokrastinasi Akademik Pada Siswa Kelas Xi Sma Negeri 1 Gombong', Jurnal Riset Mahasiswa Bimbingan dan Konseling, 5(3), pp. 254-260.

BPS (2020) 'Indeks Pembangunan Manusia 2019', Berita Resmi Statistik.

Hartantya, N. P. and Hakim, L. (2016) 'Pengaruh Fear Of Failure, Motivasi Berprestasi Dan Minat Belajar Terhadap Prokrastinasi Akademik Pada Tugas Mata Pelajaran Akuntansi Perusahaan Jasa', Journal of Economic Cooperation and Development, Volume 5 N(Program Studi S1 Pendidikan Akuntansi, Jurusan Pendidikan Ekonomi, Fakultas Ekonomi Universitas Negeri Surabaya), p. 6.

Kadi, A. P. U. (2016). Hubungan Kepercayaan Diri Dan Self Regulated Learning Terhadap Prokrastinasi Akademik Pada Mahasiswa Psikologi 2013 (Mahasiswa Psikologi Universitas Mulawarman). Ejournal.Psikologi.Fisip-

Unmul.Ac.Id, 4(4), 457-471. Http://Ejournal.Psikologi.FisipUnmul.Ac.Id/Site/WpContent/Uploads/2016/06/Ejournal Arie Prima (Online) (06-09-16-12-5520).Pdf

Margareta, R. S. and Wahyudin, A. (2019) 'Pengaruh Motivasi Belajar, Perfeksionisme dan Keaktifan Berorganisasi terhadap Prokrastinasi Akademik dengan Regulasi Diri sebagai Variabel Moderating, Economic Education Analysis Journal, 8(1), pp. 79-94.

Novera, D. A. and Thomas, P. (2018) 'Peran Kontrol Diri dalam Memediasi Pengaruh Motivasi 
Berprestasi, Perfeksionisme dan Kesulitan Ekonomi Terhadap Prokrastinasi Akademik (Studi Kasus pada Mahasiswa yang Sedang mengerjakan Skripsi FE UNNES)', Economic Education Analysis Journal, 7(1), pp. 45-58.

Oktavian, R. and Aldya, R. F. (2020) 'Integrasi Pemanfaatan Media Pembelajaran Berbasis Adobe Flash dengan Lingkungan Untuk Meningkatkan Minat Belajar Biologi', Inteligensi : Jurnal Ilmu Pendidikan, 3(1), pp. 40-46. doi: 10.33366/ilg.v3i1.1823.

Purwanti, M., Purwanti and Lestari, S. (2016) 'Pengaruh Kontrol Diri Terhadap Prokrastinasi Akademik Peserta Didik Kelas X Sma Negeri 1 Sungai Ambawang', Jurnal Pendidikan dan Pembelajaran, 5(8), pp. 1-15.

Putri, S. R., \& Siregar, I. K. (2019). Motivational

Achievement Relationship And Procrastination Academic. Biblio Couns: Jurnal Kajian Konseling Dan Pendidikan, 2(3), 105-108. Https://Doi.Org/10.30596/Bibliocoun s.V2i3.3709

Sari, M., Rahmawati, S. W. and Lestari, M. A. (2017) 'Motivasi Berprestasi Dan Prokrastinasi Akademik Pada Mahasiswa Psikologi', Psiko Utama, (May).

Setiawan, H. P. and Faradina, S. (2018) 'Perfeksionisme dengan prokrastinasi akademik dalam menyelesaikan skripsi pada mahasiswa universitas syiah kuala', Seurune, Jurnal Psikologi Unsyiah,
1(2), pp. 20-36.

Sprock, A. S. and Villalba, K. (2020) 'Relationship between academic procrastination and attributions of achievement motivation', International Journal of Learning, Teaching and Educational Research, 19(1), pp. 188-205. doi: 10.26803/ijlter.19.1.11.

Steel, P. (2007) 'The nature of procrastination: A meta-analytic and theoretical review of quintessential self-regulatory failure', Psychological Bulletin, 133(1), pp. 65-94. doi: 10.1037/00332909.133.1.65.

Sugiyono (2017) Metode Penelitian Kuantitatif, Kualitatif dan $R \& D$. Cetakan Ke. Bandung: Anggota Ikatan Penerbit Indonesia (IKAPI).

Tangney, J. P., Baumeister, R. F. and Boone, A. L. (2004) 'High self-control predicts good adjustment, less pathology, better grades, and interpersonal success.pdf', Journal of Personality, 2(April 2004), p. 54.

Triyono, \& Khairi, A. M. (2018). Prokrastinasi Akademik Siswa Sma (Dampak Psikologis Dan Solusi Pemecahannya Dalam Perspektif. $A l$ Qalam, 19(2), 58-74.

Zahraningsih, I. S. and Abdurrahman (2019) 'Hubungan Antara Kontrol Diri dan Konformitas Dengan Prokrastinasi Akademik Pada Siswa SMA Islam Sultan Agung 3 Kota Semarang', Prosiding Konferensi Ilmiah Mahasiswa UNISSULA, 000, pp. 420-427. 
Inteligensi : Jurnal Ilmu Pendidikan Vol. 4, No.1, 2021. Hal 27-36 